\title{
Influence of Teacher-Student Relationship on Academic Performance: The Case of Tirana
}

\author{
Arjana Mucaj \\ Faculty of Social Sciences, Tirana, ALBANIA \\ Department of Psychology-Pedagogy \\ Silva Ibrahimi \\ Albanian University, Tirana, ALBANIA \\ Department of Psychology \\ Denisa Gjoka ${ }^{1}$ \\ University “Alexander Moisiu”, Durres, ALBANIA
}

Received: 12 June 2020 • Accepted: 18 January 2021 - Published Online: 8 April 2021

\begin{abstract}
The aim of the current study is to assess the impact of the teacher-student relationship on the academic performance of students 12 to 15 years old in the Albanian context. The analysis and evaluation of this relationship is an important issue as a qualitative relationship between them contributes not only to the students' academic but also to their socio-emotional development. The sample was composed by 121 students selected on three 9-years school of Tirana. Factorial analysis by the statistics method showed that the internal factors that influence the teacherstudent relationship were related to individual traits as temperament, personality, ability, and psychological effects. It is precisely the role of the teacher through communication and meeting the needs of the student that influences the student's perception of behavior, competence, care, and support from the teacher. Classroom climate was an external factor that also affect the teacher-student relationship. It is precisely positive relationships that induce a good environment and foster motivation and high results. A qualitative teacher-student relationship affects academic and psycho-social development of student in the class.
\end{abstract}

Keywords: teacher-student relation, academic performance, internal factors, external factors.

\section{Introduction}

The main aim of the study is to assess the impact of the teacher-student relationship on the academic performance of students of 12 to 15 years old in the Albanian context. The primary research was based on the analysis of data collected at three 9-year schools in Tirana, Albania. It deals with the way in which students view and interpret the relationship with teachers and the impact of this relationship on their academic outcomes (Osbuth et al., 2016).

${ }^{1}$ Student at University “Alexander Moisiu”, Durres, ALBANIA.

(C) Authors. Terms and conditions of Creative Commons Attribution 4.0 International (CC BY 4.0) apply. Correspondence: Silva Ibrahimi (PhD), Albanian University, Department of Psychology, Tirana, ALBANIA. E-mail: silva.ibrahimi@yahoo.it. 
A. Mucaj, S. Ibrahimi \& D. Gjoka - Influence of Teacher-Student Relationship on Academic ...

The basic research question that needs to be answered here is: Is there a significant relationship between the teacher-student relationship and academic performance of 12-15 y.o. students?

Three core hypotheses were assessed in the present research:

$H_{1}$. Characteristics of teachers influence the quality of their relationship

with the students.

This hypothesis aims to assess the impact of temperament, teacher behavior, and students' individual perceptions on the teacher-student relationship. A teacher who accepts suggestions and opinions and responds to students politely, has a qualitative teacher-student relationship.

$H_{2}$. A good teacher-student relationship affects positively on the student involvement in learning.

This hypothesis aims to assess the methods and ways that stimulate students' needs for connection, competence, and autonomy that affect engagement in the learning process.

$H_{3}$. The classroom climate affects students'academic performance.

The hypothesis aims to assess how a good environment promotes a high level of motivation. High levels of motivation are seen as an element that tends to enhance positively the academic outcomes.

The significant role of the teacher in the academic and lifetime success of students has been provided also by research (Blazar, 2015; Chetty, Friedman \& Rockoff, 2014). Pianta, Hambre and Allen (2012) over the years conducted research on the impact of the teacher-student relationship on the academic outcomes of preschoolers, elementary and high-school education students. For the quality of teacher and student dyad a number of studies observed different aspects related to the relationship including support for autonomy, the emotional path influence, assessing classroom interaction, teacher empathy, students' perceptions of the relationship, teachers' perceptions, organization and classroom climate, feedback, communication and the teaching methods (Pianta, Hamre \& Allen, 2012). Another study was also performed to confirm how classroom effects affected the outcomes of elementary school children (Pianta, Belsky, Vandergrift, Houts \& Morrison, 2008). These studies have found that a positive relationship between teachers and students and student's support, would lead to significant improvements in the academic performance. There is also literature that highlights the impact of gender differences on teacher-student relationships and academic performance. Boys perceive being least supported and also more conflictual with the teacher regarding grades, than girls (Wu, Hughes \& Kwok, 2010; Baker, 2006; Ryan \& Deci, 1994). A positive teacher-student relationship enhances student involvement and participation in learning. Positive relations make students feel more motivated and engaged in the learning world. They also tend to work harder in the classroom, are persistent, accept instruction and criticism, cope better with stress, and pay more attention to teachers (Little \& Kobak, 2003).

A student has a "successful performance" at the school if he "engages" within the institution the time needed to take place all the changes expected in terms of learning outcomes. The "expected changes" in the students completing their studies (Pascarella \& Terenzini, 2005) are represented by:

- the acquisition of specific disciplinary skills, typically assessable with the number of competences and skills acquired, the marks obtained, the results to the verification tests or the positions in ranking achieved (the performance variables). 
- the occurrence of a less standardized psychosocial changes that relate to the sense of identity, self-esteem, self-efficacy beliefs, the meta-cognition and intellectual growth (Eccles \& Wigfield, 2002; Harackiewicz, Barron, Pintrich, Elliot \& Thrash, 2002).

- the acquisition of the so-called transversal skills or the skills necessary for the organization and fulfillment of school assignments and exam preparation (Elliot, McGregor \& Gable, 1999; Anderson, Bonta \& Thorn, 2002; Ferrett, 2000).

According to Pianta et al. (1992) who examined these events as a dynamic model of cause-effect, weak relationships with teachers emerge feelings of insecurity and anxiety in children. They also can prevent them gaining pleasure from learning and social activities (Hughes, 2012). Context, which is reflected in the characteristics of the teacher and the classroom environment, should be regarded as a changing dynamic that provides new opportunities to the teacher-student relationship. Studies examining stability in the teacher-student relationship have generally revealed a moderate stability from year-to-year indicating that dynamic impacts both stable features of the student and their changing contexts (Jerome, Hamre \& Pianta, 2008). Therefore, interventions focused on improving academic achievement should give priority to the quality of the relationship (Yunus, Osman \& Ishak, 2011). The present research explores the impact that the teacher-student relationship has on students' academic performance.

\section{Methods and procedures \\ 2.1 Sample}

Participants of the current study are 130 students who are currently enrolled in 9-year schools in Tirana. The range of ages of the sample is 12 to 15 years old on a random selection from which 68 males (57\%) and 52 females (43\%) $(\mathrm{M}=19.4$; $\mathrm{SD}=1.4)$. Data of the nine participants were excluded from the study due to the failure to complete a significant part of the instrument and the final sample consisted of 121 participants. The current research project was approved by the Order of Psychologists of Albania research ethics committee. The questionnaire was administered at an anonymous-based response and respondents were informed that none of the data coming from the survey would be linked to a specific identity.

\subsection{Statistical procedure}

All data collected were subjected to a series of psychometric procedures and tests using SPSS 23. Descriptive analysis was performed to examine the data characteristics of all variables, which include mean, standard deviation. Then, the relative chi-square test $\left(\chi^{2} / d f\right)$, variance evaluation and multiple regression were performed.

\subsection{Measures}

Two instruments were used for the data collection and analysis of the study:

The first tool used is the "Student-teacher relationship scale", a certified questionnaire firstly presented by Abdulrahman (2007) in the paper "Student's views on student-teacher relationship: A questionnaire-based study". The questionnaire is divided into four sections with a total of 22 questions. For each of the questions, students are asked to indicate the degree to which statements are characteristic of their teacher relationship and performance in a Likert scale $(1=$ strongly disagree to $4=$ strongly agree). The first section of the questionnaire consists on the students' views on teachers related to their academic grades. In the second section it is aimed to assess the students' views on participation, controlling destructive behavior in the classroom, and 
A. Mucaj, S. Ibrahimi \& D. Gjoka - Influence of Teacher-Student Relationship on Academic ...

the effect of relationship on academic grades. The third section regards the students' views on different aspects of the relationship and their assessment. The fourth section is composed of two open-ended questions that include the perceived teacher characteristics by the student. Table 1 presents the features of internal stability and validity of the used questionnaire.

Table 1. Questionnaire internal stability and validity

\begin{tabular}{|c|c|c|c|}
\hline Questionnaire & $\begin{array}{l}\text { Cronbach's } \\
\text { no. }=170\end{array}$ & Alpha & No.of questions \\
\hline $\begin{array}{l}\text { 1. Individual characteristics of } \\
\text { teachers and students }\end{array}$ & .851 & & 5 \\
\hline $\begin{array}{l}\text { 2. Students' involvement and } \\
\text { participation }\end{array}$ & .871 & & 10 \\
\hline 3. Classroom environment & .908 & & 7 \\
\hline
\end{tabular}

The total internal stability calculated with the Cronbach's Alpha for all the 22 questions is equal to 0.782 .

The second evaluation tool related to the academic performance and involvement in learning. Mark records were analyzed and semi-structured interviews were conducted to ask students about their progress in the school during the last 6 months.

\section{Results}

From the analysis of the questionnaire in the examination of the first hypothesis $\left(\mathrm{H}_{1}\right)$ the general regression model is significant as $\mathrm{F}(3,117)=57.889, \mathrm{p}<0.001, \mathrm{R}$ square $=0.597 . \mathrm{H}_{1}$ is not rejected.

In the coefficients table matrix, for every independent variable, the significance of each variable is considered separately. Thus, an independent variable was significant separately when $\alpha$ (.05) and compared with three p-values for each of the independent variables respectively $(0.000,0.014,0.000)<0.05$. From the variance analysis of the hypothesis, it resulted that $\mathrm{F}(\mathrm{df}=$ 3) $=57.889$.

$\mathrm{H}_{1}$ therefore, is statistically significant $\mathrm{F}=57.889>$ Critical $\mathrm{F}(\alpha=0.05)=3.68$.

From the Chi-square analysis, $\chi^{2}(\mathrm{df}=9)=84.253$. The greater the Chi-square, the more likely it is to have a relationship between the variables considered. Thus $\mathrm{p}<0.05$ indicates that the individual teacher and student traits affect the quality of their relationship.

Our second hypothesis aims to assess the methods and ways that trigger student's needs for connection, competencies and autonomy and that affect learning involvement.

The general regression model is significant as $\mathrm{F}(3,117)=31.271, \mathrm{p}<0.001, \mathrm{R}$ square $=$ 0.445. That means not only that the regression was statistically significant, but also that the gender of the students has an impact on the perception-quality of the teacher-student relationship. In the coefficients table matrix, for each independent variable, the significance is considered separately. Results revealed that the independent variable was significant $\alpha$ (.05) and compared with three pvalues for each of the independent variables respectively $(0.031 ; 0.000)<0.05$.

From the variance analysis of the hypothesis, it resulted that $\mathrm{F}(\mathrm{df}=3)=31.271$. Hypothesis $\mathrm{H}_{2}$ is significant as $\mathrm{F}=31.271>$ Critical $\mathrm{F}(\alpha=0.05)=3.68$.

From the Chi-square test, $\chi^{2}(\mathrm{df}=9)=113.142$. The greater the Chi-square value, the more likely it is to have a relationship between the variables considered. $\mathrm{p}<0.05$ reveals that a good student-teacher relationship positively influences student involvement and participation in 
the learning process. The third hypothesis regard the classroom climate and its impact on the academic performance of students. The general regression model is significant as $F(4,116)=$ $18.583, \mathrm{p}<0.001$, $\mathrm{R}$ square $=0.391$. Therefore, the regression was statistically significant as the characteristics of the classroom environment are related to academic performance and learning outcomes. In the coefficients table matrix, for each independent variable, the significance of each variable is considered separately. The independent variable was significant separately. $\alpha$ (.05) and compared with three $\mathrm{p}$-values for each of the independent variables respectively $(0.005,0.001)$ $<0.05$. From the Chi-square analysis, $\chi^{2}(\mathrm{df}=9)=35.927$. The greater the Chi-square value, the more likely it is to have a relationship between the variables to be considered. As $\mathrm{p}<0.05$ we can conclude that the characteristics of the classroom environment are related to academic performance - student outcomes.

\section{Discussion}

The main purpose of the current paper is to assess the impact of the teacher-student relationship on the academic performance of 12- to 15-year-old in the Albanian context. Firstly, to determine whether the assessment made by the students is valid and reliable, a model constructed using SPSS was analyzed.

The constructed pattern explained the validity of the responses. Subsequently, several hypotheses were raised and analyzed through the statistical software. The hypotheses were constructed to evaluate if there were any relationships between the variables with the purpose of showing which factors affect students' ratings between variables.

From the analysis of the first it is revealed that individual features of teachers and students affect the quality of their relationship. Temperament, teacher's behavior and students' individual perceptions impact the overall quality of the academic relationship. This hypothesis confirms the theoretical basis previously analyzed by Pianta who explained the teacher-student relationship through a conceptual model. The main factors involved in his proposed relationship model were: (1) individual features, (2) the process by which information is exchanged between stakeholders and (3) external factors. In terms of individual traits, it included: demographic, psychological and developmental factors. Individual traits also include gender, temperament, personality, competencies and self-esteem. Teachers' perceptions and beliefs about students and their role are important in developing positive and encouraging relationships in the classroom.

Other significant data from the analysis of the present research, showed that students' gender also affect their perception of their relationship with the teachers and school academic results. Female respondents have shown a greater influence and closeness to the student-teacher relationship than males. Based on the perspective of gender role socialization, girls benefit more from close relationships with the teacher because closeness is consistent with the greater intimacy and attachment to social relationships expected by females (Maccoby, 1998). Girls are also more inhibited from conflicting relationships with teachers because behaviors as conflict or dominance are seen more in boys than in girls (Ewing \& Taylor, 2009). The second hypothesis analysis showed that a good teacher-student relationship positively influences student involvement and participation in learning. Thus, the way the teacher organizes the course, as it meets the students' needs for connection, competence and autonomy, influence the engagement in the learning process. One of the questions we raised to control "Student involvement and participation" variable, is "In general I trust my teacher's advice".

From multiple regression analysis, the coefficients table showed that this independent variable is not a significant predictor on the impact of teacher-student relationship and student involvement. This is not very surprising as all students, regardless of their relationship with the teacher or their participation, are for the most part aware that teacher advice is reliable. 
A. Mucaj, S. Ibrahimi \& D. Gjoka - Influence of Teacher-Student Relationship on Academic ...

The third hypothesis was controlled by the validity of classroom climate and its influence on the students' academic performance. Classroom climate (characteristics of the classroom environment, student involvement and participation in learning) affect students' academic performance. A good environment promotes motivation which in turn is seen as an element that tends to positively enhance academic performance. This is also confirmed by the theoretical basis that teacher-student interactions predict positive developments for all children as well as filling in the gaps of children with different risk groups (Brophy \& Good, 1986; Gage \& Needels, 1989; Rimm-Kaufman, Storm, Sawyer, Pianta \& La Paro, 2006; Skinner \& Belmont, 1993; Stipek, 1998). Another supporting argument was given by the research of Patrick et al. who considered class context as a significant tool of achievement (Patrick, Mantzicopoulos \& Sears 2012). Not only classroom environment, but also the emotional support and guidance of the teacher play a significant role on the engagement and involvement of students in the learning process and academic achievement (Pianta, La Paro, Payne, Cox \& Bradley, 2002). One of the questions we raised to control the "Characteristics of the classroom environment" variable, is "In your opinion, if there is a disruption in the classroom, the teacher's most appropriate action is to exclude the class?" and "In your opinion, if there is a disruption in the classroom, the teacher's most appropriate action is to ignore it?" Data analysis revealed that both reactions are not significant predictors of the impact on the perception of classroom environment characteristics and the resulting connection with academic performance and student outcomes. This is normal as all students, regardless of their relationship or their participation in the classroom, influenced by contemporary teaching methods, have been faced with inclusive rather than exclusionary or ignoring teacher behaviors. Meeting students' needs leads to increased engagement in the class. Student participation in learning has a positive impact on academic achievement.

\section{Conclusions}

In conclusion, we can say that throughout its psychogenic evolution, the relationship between teacher and students' characteristics plays a significant role on the quality of the relation of them. This is highlight even by relative research as Zamarro et al. (Zamarro, Engberg, Saavedra \& Steel, 2015). Individual traits of teachers and students, the way the teacher manages the classroom, temperament, approach to learning and students, affects the quality of the teacherstudent relationship are important factors in influencing the quality of the latter relationship. Gender is an important feature in developing supportive relationships in the classroom that influences a student's perception of their relationship with the teacher and school outcomes.

Meeting students' needs for connection, competence and autonomy, affect the latter engagement and participation in the learning process. So, a good teacher-student relationship creates an inclusive classroom where each class member finds himself engaged.

The classroom climate is an important external factor where the characteristics of the classroom environment and student engagement positively influence and motivate academic achievement. The internal factors that influence the teacher-student relationship include individual traits as temperament, personality, ability and psycho-social dynamics. It is the role of the teacher through communication and meeting the student's needs that influences the student's perception of behavior, competence, care and supporting networks from the teacher.

\section{Acknowledgements}

This research did not receive any specific grant from funding agencies in the public commercial, or not-for-profit sectors.

The authors declare no competing interests. 


\section{References}

Abdulrahman, K. B. A. (2007). Students views on student-teacher relationship: A questionnaire-based study. Journal of Family Community Medicine, 14(2), 81-87.

Anderson, D. L., Bonta, M., \& Thorn, P. (1998). New and noteworthy bird records from Honduras. Bull. Br. Ornithol. Club 118: 178-183.

Baker, J. A., Grant, S., \& Morlock, L. (2008). The teacher-student relationship as a developmental context for children with internalizing or externalizing behavior problems. School Psychology Quarterly, 23(1), 3-15.

Blazar, D. (2015). Effective teaching in elementary mathematics: Identifying classroom practices that support student achievement, Economics of Education Review, 48, 16-59.

Brophy, J., \& Good, T. (1986). Teacher behavior and student achievement. In M. C. Wittrock (Ed.), Handbook of research on teaching ( $3^{\text {rd }}$ ed., pp. 328-375). New York, NY: Macmillan.

Chetty, R., Friedman, J. N., \& Rockoff, J. E. (2014). Measuring the impacts of teachers II: Evaluating bias in teacher value-added estimates. American Economic Review, 104(9), 2593-2632.

Eccles, J. S., \& Wigfield, A. (2002). Motivational beliefs, values, and goals. Annual Review of Psychology, $53,109-132$.

Elliot, A. J., McGregor, H. A., \& Gable, S. (1999). Achievement goals, study strategies, and exam performance: A mediational analysis. Journal of Educational Psychology, 91, 549-563.

Ewing, A. R., \& Taylor, A. R. (2009). The role of child gender and ethnicity in teacher-child relationship quality and children's behavioral adjustment in preschool. Early Childhood Research Quarterly, 24(1), 92-105. https://doi.org/10.1016/j.ecresq.2008.09.002

Gage, N. L., \& Needles, M. C. (1989). Process-product research on teaching: A review of criticisms. Elementary School Journal, 89, 253-300.

Good, T., \& Brophy, J. (1986). School effects. In M. Wittrock (Ed.), Handbook of research on teaching (3 ${ }^{\text {rd }}$ ed.) (pp. 570-602). New York: Macmillan.

Harackiewicz, J., Barron, K. E., Pintrich, P., Elliot, A., \& Thrash, T. (2002). Revision of achievement goal theory: Necessary and illuminating. Journal of Educational Psychology, 94, 638-645.

Jerome, E. M., Hamre, B. K., Pianta, R. C. (2009). Teacher-child relationships from kindergarten to sixth grade: Early childhood predictors of teacher-perceived conflict and closeness. Social Development, 18(4), 915-945.

Maccoby, E. E. (1998). The two sexes: Growing up apart, coming together. Cambridge, MA: Harvard University Press.

Little M., \& Kobak R. (2003). Emotional security with teachers and children's stress reactivity: A comparison of special-education and regular-education classrooms. Journal of Clinical Child \& Adolescent Psychology, 32, 127-138

Obsuth, I., Murray, A. L., Malti T., Sulger, Ph., Ribeaud, D., \& Eisner M. (2016). A non-bipartite propensity score analysis of the effects of teacher-student relationships on adolescent problem and prosocial behavior, 46(8), 1661-1687. https://doi.org/10.1007/s10964-016-0534-y

Patrick, H., Mantzicopoulos, P., \& Sears, D. (2012) Effective classrooms. In K. R. Harris, S. Graham \& T. Urdan (Eds.), APA Educational psychology handbook. Volume 2: Individual differences and cultural and contextual factors (pp. 443-469). Washington DC: American Psychological Association. 
A. Mucaj, S. Ibrahimi \& D. Gjoka - Influence of Teacher-Student Relationship on Academic ...

Pianta, R. C., Hamre, B. K., \& Allen, J. P. (2012). Teacher-student relationships and engagement: conceptualizing, measuring and improving the capacity of classroom interactions. Handbook of research on student engagement, 365-386.

Pianta, R. C., Belsky, J., Vandergrift, N., Houts, R., \& Morrison, F. J. (2008). Classroom effects on children's achievement trajectories in elementary school. American Educational Research Journal, 45(2), 365-397.

Pianta, R. C., La Paro, K. M., Payne, C., Cox, M. J., \& Bradley, R. (2002). The relation of kindergarten classroom environment to teacher, family, and school characteristics and child outcomes. Elementary School Journal, 102(3), 225-238. https://doi.org/10.1086/499701

Rimm-Kaufman, S. E., Storm, M., Sawyer, B., Pianta, R. C., \& La Paro, K. (2006). The Teacher Belief Q-Sort: A measure of teachers' belief in relation to disciplinary practices, teaching practices, and beliefs about children. Journal of School Psychology, 44, 141-165.

Robbins, S., Davenport, M., Anderson, J., Kliewer, W., Ingram, K., \& Smith, N. (2002). Motivational determinants and coping and academic behavior mediators of first year college adjustment: A prospective study. Manuscript submitted for publication.

Ryan, R. M., Deci, E. L. (2000). Self-Determination Theory and the facilitation of intrinsic motivation, social development and well-being. American Psychologist, 55(1), 68-79.

Skinner, E. A., \& Belmont, M. J. (1993). Motivation in the classroom: Reciprocal effects of teacher behavior and student engagement across the school year. Journal of Educational Psychology, 85, 571581 .

Stipek, D. (1988). Motivation to learn: From theory to practice. Englewood Cliffs, NJ: Prentice Hall.

Yunus, M. M., Osman, W. S. W., \& Ishak, N. M. (2011). Teacher-student relationship factor affecting motivation and academic achievement in ESL classroom. Procedia Social and Behavioral Sciences, 15, 2637-2641.

Wu, Y.-J., Hughes, N. J., \& Kwok, O.-M. (2010). Teacher-student relationship quality type in elementary grades: Effects on trajectories for achievement and engagement, Journal of School Psychology, 48(5), 357-87. https://doi.org/10.1016/j.jsp.2010.06.004

Zamarro, G., Engberg J., Saavedra J. E., \& Steel, J. (2015). Disentangling disadvantage: Can we distinguish good teaching from classroom composition? Journal of Research on Educational Effectiveness, 84-111. https://doi.org/10.1080/19345747.2014.972601 